\title{
GAMBARAN PERANAN PENYULUHAN METODE DEMONSTRASI TERHADAP PENGETAHUAN MENYIKAT GIGI PADA SISWA/I KELAS IV SD 068003 KAYU MANIS PERUMNAS SIMALINGKAR KECAMATAN MEDAN TUNTUNGAN
}

\author{
Sri Junita Nainggolan \\ Jurusan Keperawatan Gigi Poltekkes Kemenkes RI Medan
}

\begin{abstract}
Brushing teeth is one of the methods to maintain dental hygiene and oral health. It can ward off the incidence of caries. In general, dental and oral health education is obtained from counseling. The group of people that usually becomes the target is elementary school children because the age of 6-14 years is a transition period or the change in permanent teeth (mixed teeth period).

In this research, the counseling was the one with demonstration method which was aimed to increase the knowledge of brushing teeth in Grade IV students at SD 068003 Kayu Manis, Perumnas Simalingkar, Medan Tuntungan Subdistrict with 30 students as the samples.

The result of the research showed that before the counseling, 18 respondents (60\%) were in good criteria in their knowledge of brushing teeth correctly and 11 respondents (36.7\%) were in moderate category. After the counseling with demonstration method, all respondents (100\%) were in good category.

The conclusion was that counseling with demonstration method could improve students' knowledge of brushing teeth. It is recommended that Grade IV students at SD 068003 brush their teeth properly and correctly.
\end{abstract}

Keywords : Demonstration Method, Knowledge of Brushing Teeth

References : 13 (1995-2016)

\section{PENDAHULUAN}

Derajat kesehatan masyarakat dipengaruhi oleh empat faktor utama, yakni: lingkungan, perilaku, pelayanan kesehatan, dan keturunan (herediter). Karena itu upaya untuk memelihara dan meningkatkan derajat kesehatan masyarakat harus ditujukan pada keempat faktor utama tersebut secara bersama-sama (Notoatmodjo, 2012). Melalui Riskesdas (Riset Kesehatan Dasar) 2013, dilakukan pengumpulan data berbagai indikator kesehatan gigi dan mulut masyarakat dengan jumlah keseluruhan 1.027.763 orang. Perilaku pemeliharaan kesehatan gigi dan mulut (umur $>10$ tahun) dengan jumlah sampel 835.256 respondendan pemeriksaan gigi serta melihat kondisi gigi dan mulut (umur $>12$ tahun) dengan jumlah sampel 789.771 responden.Prevalensi nasional masalah gigi dan mulut adalah 25,9 \% sebanyak 14 provinsi Prevalensi nasional menyikat gigi setiap hari adalah $94,25 \%$ sebanyak 15 provinsi berada dibawah prevalensi nasional. Perilaku yang benar dalam menyikat gigi berkaitan dengan faktor gender, ekonomi, dan daerah tempat tinggal. Sebagian besar penduduk Indonesia menyikat gigi pada saat mandi pagi maupun mandi sore $(76,6 \%)$.

Pendidikan atau promosi kesehatan pada hakikatnya adalah upaya intervensi yang ditujukan pada faktor perilaku. Namun pada kenyataannya tiga faktor yang lain perlu intervensi pendidikan atau promosi kesehatan juga, karena perilaku juga berperan pada faktorfaktor tersebut. Apabila lingkungan baik dan sikap masyarakat positif maka lingkungan dan fasilitas tersebut niscaya akan dimanfaatkan atau digunakan oleh masyarakat (Notoatmodjo,2012). Pada umumnya promosi kesehatan gigi diperoleh dari penyuluhan.

Penyuluhan adalah suatu proses belajar secara nonformal kepada sekelompok masarakat tertentu, dimana pada penyuluhan kesehatan gigi dan mulut diharapkan terciptanya suatu pengertian yang baik mengenai kesehatan gigi dan mulut. Kelompok masyarakat yang sering dituju untuk memberikan penyuluhan adalah anak-anak sekolah dasar karena pada masa usia sekolah dasar adalah masa transisi dalam interaksi sosial dimana terjadi perubahan pada diri anak.

Pendidikan kesehatan gigi di sekolah merupakan suatu system pendidikan nonformal bagi masyarakat sekolah dengan cara belajar sambil berbuat untuk mengubah perilaku mereka dari yang kurang menguntungkan terhadap kesehatan gigi dan mulutnya. Melalui kegiatan ini diharapkan mereka menjadi tahu, mau dan mampu memecahkan berbagai persoalan yang dihadapi, baik secara sendiri maupun bersama, guna terus meningkatkan kesehatan gigi dan mulutnya sendiri, serta keluarganya. 
Berdasarkan uraian di atas maka penulis tertarik melakukan penelitian tentang gambaran peranan penyuluhan metode demonstrasi terhadap pengetahuan menyikat gigi pada siswa/i kelas IV SD 068003 Kayu Manis Perumnas Simalingkar, Kecamatan Medan Tuntungan.

\section{Tujuan Penelitian}

Penelitian dilakukan bertujuan untuk mengetahui Gambaran Peranan Penyuluhan Metode Demonstrasi Terhadap Pengetahuan Menyikat Gigi Pada Siswa/i Kelas IV SD 068003 Kayu Manis Perumnas Simalingkar, KecamatanMedan Tuntungan.

Manfaat Penelitian

Data yang diperoleh dari penelitian diharapkan dapat digunakan

1. Sebagai informasi dan bahan masukan bagi sekolah dalam melaksanakan Program UKGS (Usaha Kesehatan Gigi Sekolah) bekerja sama dengan Puskesmas setempat.

2. Menambah wawasan peneliti dalam memberikanpenyuluhan denganmetode demonstrasi.

3. Sebagai sumber data dan informasi bagi peneliti yang sejenis.

\section{METODE PENELITIAN}

\section{Jenis dan Desain Penelitian}

Jenis penelitian yang dilakukan adalah penelitian deskriptif dengan metode survey yang betujuan untuk mengetahui Gambaran Peranan Penyuluhan Metode Demonstrasi Terhadap Pengetahuan Menyikat Gigi Pada Siswa/i Kelas IV SD 068003 Kayu Manis Perumnas Simalingkar, KecamatnMedan Tuntungan.

\section{POPULASI DAN SAMPEL}

Populasi adalah keseluruhan objek penelitian atau objek yang diteliti.Populasi dalam penelitian ini adalah siswa/i kelas IV SD 068003 Kayu Manis Perumnas Simalingkar, Kecamatan Medan Tuntungan yang berjumlah 30 orang.

Sampel adalah sebagian atau wakil populasi yang diteliti (Arikunto, S., 2006).Apabila objeknya kurang dari 100 orang, lebih baik sampel diambil semua.Dalam penelitian ini yang menjadi sampel adalah siswa/i kelas IV SD 068003 Kayu Manis Perumnas Simalingkar, Kecamatan Medan Tuntungan yang berjumlah 30 orang.

\section{HASIL DAN PEMBAHASAN}

\section{Hasil Penelitian}

Berdasarkan penelitian yang dilakukan pada siswa/i kelas IV SD 068003 Kayu Manis Perumnas Simalingkar, Kec. Medan Tuntungan Tahun 2016 maka data yang terkumpul dapat dibuat dengan tabel distribusi frekuensi sebagai berikut:

Tabel 4.1 Distribusi Frekuensi Tingkat Pengetahuan Siswa/i Sebelum Penyuluhan DenganMetode Demonstrasi Terhadap Pengetahuan Menyikat Gigi
PadaSiswa/i Kelas IV SD 068003 Kayu Manis Perumnas Simalingkar Kecamatan Medan Tuntungan

\begin{tabular}{ccc}
\hline Kriteria & $\mathbf{n}$ & $\mathbf{( \% )}$ \\
\hline Baik & 15 & 50 \\
Sedang & 14 & 46,7 \\
Buruk & 1 & 3,3 \\
\hline Jumlah & $\mathbf{3 0}$ & $\mathbf{1 0 0}$ \\
\hline
\end{tabular}

Berdasarkan tabel 4.1 diperoleh bahwa tingkat pengetahuan siswa/i sebelum penyuluhan dengan metode demonstrasi terhadap pengetahuan menyikat gigi dengan kriteria baik sebanyak 15 siswa/i $(50 \%)$, kriteria sedang sebanyak 14 siswa/i (46,7\%) dan kriteria buruk sebanyak 1 siswa/i (3,3\%).

Tabel 4.2 Distribusi Frekuensi Tingkat Pengetahuan Siswa/i Setelah Penyuluhan Dengan Metode Demonstrasi Terhadap Pengetahuan Menyikat Gigi Pada Siswa/i Kelas IV SD 068003 Kayu Manis Perumnas Simalingkar KecamatanMedan Tuntungan.

\begin{tabular}{ccc}
\hline Kriteria & $\mathbf{n}$ & $\mathbf{( \% )}$ \\
\hline Baik & 30 & 100 \\
Sedang & 0 & 0 \\
Buruk & 0 & 0 \\
\hline Jumlah & $\mathbf{3 0}$ & $\mathbf{1 0 0}$ \\
\hline
\end{tabular}

Berdasarkan tabel 4.2 diperoleh bahwa tingkat pengetahuan anak setelah penyuluhan dengan menggunakan metode demonstrasi terhadap pengetahuan menyikat gigi dengan kriteria baik sebanyak 30 siswa/i (100\%). Namun masih terdapat 2 siswa $(6,67 \%)$ yang menjawab salah.

\section{Pembahasan}

Berdasarkan penelitian yang dilakukan pada siswa/i kelas IV SD 068003 Kayu Manis Perumnas Simalingkar, Kec. Medan Tuntungan Tahun 2016 yang berjumlah 30 siswa dengan rata-rata usia 9-10 tahun, ditemukan bahwa dalam tabel 4.1 distribusi frekuensi tingkat pengetahuan anak sebelum penyuluhan dengan metode demonstrasi dengan kriteria baik 50\%, untuk kriteria sedang 46,7\%, dan untuk kriteria buruk $3,3 \%$. Sebagian besar siswa/i $(66,7 \%)$ belum mengetahui lamanya menyikat gigi dan hanya 10 siswa/i $(33,3 \%)$ yang sudah mengetahui lamanya menyikat gigi yang baik dan benar yaitu 2-3 menit, hal ini sesuai dengan pendapat Panjaitan, M., (1995), umumnya orang menyikat gigi maksimal 2-3 menit. Bila menyikat gigi dilakukan dalam waktu yang singkat, maka hasilnya tidak begitu baik daripada bila menyikat gigi dalam waktu yang lama, mengingat banyaknya permukaan gigi yang harus dibersihkan.

Sebelum penyuluhan dengan metode demonstrasi sebagian besar siswa/i (60\%) belum mengetahui frekuensi menyikat gigi, hanya 12 siswa/i $(40 \%)$ yang sudah mengetahui frekuensi menyikat gigi. Menurut Manson 
(1971, cit. Putri, M., dkk., 2010), berpendapat bahwa penyikatan gigi sebaiknya dilakukan dua kali sehari.

Sebagian besar siswa/i (60\%) belum mengetahui cara menyikat gigi bagian labial (menghadap bibir), dan 43,3\% siswa/i tidak mengetahui cara menyikat gigi bagian bukal (menghadap pipi). Menurut Pratiwi, D., (2009) ada beberapa tips singkat yang harus diketahui ketika menggosok gigi, diantaranya adalah untuk menyikat gigi bagian depan atau bagian bibir caranya adalah dengan memegang sikat dan menggosokkannya pada gigi bagian depan dengan arah naik turun secara merata. Untuk gigi bagian pipi sikatlah gigi dengan cara membulat.

Diperoleh frekuensi distribusi pengetahuan anak sebelum penyuluhan metode demonstrasi dengan kriteria baik $50 \%$, kriteria sedang 46,7\%, dan untuk kriteria buruk $3,3 \%$, untuk frekuensi distribusi pengetahuan anak setelah penyuluhan dengan menggunakan metode demonstrasi dengan kriteria baik dari $50 \%$ menjadi $100 \%$, dan tidak terdapat kriteria sedang dan buruk. Dari data tersebut diketahui bahwa tingkat pengetahuan anak dengan metode demonstrasi meningkat, hal ini sesuai dengan keuntungan pembelajaran dengan metode demonstrasi menurut Susilo(2011) yang menyatakan bahwa penyuluhan menggunakan metode demonstrasi dapat meningkatkan konsentarsi, kesalahan yang timbul lebih minimal dibandingkan dengan metode lain, serta keterampilan psikomotor tercapai.

\section{SIMPULAN DAN SARAN}

\section{Simpulan}

Berdasarkan hasil penelitian yang telah dilakukan dapat diambil suatu kesimpulan :

1. Diperoleh bahwa tingkat pengetahuan anak sebelum penyuluhan dengan metode demonstrasi terhadap pengetahuan menyikat gigi dengan kriteria baik sebanyak 15 siswa/i $(50 \%)$, kriteria sedang sebanyak 14 siswa/i $(46,7 \%)$ dan kriteria buruk sebanyak 1 siswa/i $(3,3 \%)$.

2. Diperoleh bahwa tingkat pengetahuan anak setelah penyuluhan dengan menggunakan metode demonstrasi terhadap pengetahuan menyikat gigi dengan kriteria baik sebanyak 30 siswa/i (100\%).

\section{Saran}

Berkaitan dengan hasil penelitian diatas, maka peneliti memberikan saran sebagai berikut :

1. Hasil penelitian ini diharapkan dapat menambah pengetahuan menyikat gigi pada siswa/i kelas IV SD 068003 Kayu Manis Perumnas Simalingkar, Kec. Medan Tuntungan.

2. Hasil penelitian diharapkan dapat menjadi bahan masukan bagi peneliti dalam memberikan penyuluhan dengan metode demonstrasi terhadap tingkat pengetahuan menyikat gigi. selalu menyikat gigi dengan cara yang baik dan benar

\section{DAFTAR PUSTAKA}

Absah,2011,PenyuluhanKesehatan,http://id.wikipedia.org/ wiki/Penyuluhan Kesehatan?oldid=921133, 21 Januari 2016

Machfoedz, I., 2008. Menjaga Kesehatan Gigi dan Mulut Anak-anak dan Ibu Hamil. Yogyakarta: Fitramaya

Mubarak, W., dkk, 2007. Promosi Kesehatan Sebuah Pengantar Proses Belajar Mengajar dalam Pendidikan, Yogyakarta: Graha Ilmu

Notoatmodjo, S., 2003. Metodologi Penelitian Kesehatan. Jakarta: Rineka Cipta

, 2005. Promosi Kesehatan dan Perilaku Kesehatan. Jakarta: Rineka Cipta

, 2012. Promosi Kesehatan dan Perilaku Kesehatan. Jakarta: Rineka Cipta

Panjaitan, M., 1995. Ilmu Pencegahan Karies Gigi. Medaan: USU Press

Pintauli, S., 2008.Menuju Gigi dan Mulut Sehat. Medan: USU Press

Pratiwi, D., 2009. Gigi Sehat daan Cantik. Jakarta: Buku Kompas

Putri, M., et al., 2010.Ilmu Pencegahan Penyakit Jaringan Keras dan Jaringan Pendukung Gigi. Jakarta: Penerbit Buku Kedokteran EGC

Riskesdas, 2013, Gigi dan Mulut. Avalaibe at http://www.depkes.go.id/resources/download/Hasil \%20Riskesdas\%202013.pdf.[AccesedFebruari 2016]

Susilo, R., 2011. Pendidikan Kesehatan dalam Keperwatan. Yogyakarta: Nusa Medika

Syafrudin, dkk., 2010. Untaian Materi Penyuluhan KIACara Menggosok Gigi. Jakarta: Trans Info Media 